\title{
Mobile Learning-system usage: Scale development and empirical tests
}

\author{
An integrated framework to measure students' behavioural intention
}

\author{
Saleh Alharbi \\ School of ICT, Griffith University \\ Gold Coast, Australia \\ Shaqra University, Saudi Arabia
}

\author{
Steve Drew \\ School of ICT, Griffith University \\ Gold Coast, Australia
}

\begin{abstract}
Mobile technologies have changed the shape of learning for learners, society, and education providers. Consequently, mobile learning has become a core component in modern education. Nevertheless, introducing mobile learning systems does not automatically guarantee that learners will develop a positive behavioural intention to use it and therefore use it. Thus, acceptance-of-technology and system-success studies have increased. As yet, however, much of the research regarding understanding students' behavioural intention to use mobile learning systems seems to suffer from several shortcomings. On top of that, there is no common cognitive theoretical foundation. This study introduces a theoretical framework that combines the Unified Theory of Acceptance and Use of Technology (UTAUT) and Information System (IS) Success Model. This integration resulted in three success measures and two acceptance constructs. The success measures included the following: a) information quality, b) system quality, and c) user satisfaction; whilst the following were the acceptance measures: a) effort expectancy, b) performance expectancy, and c) social influence. Further, this study introduces lecture attitude as a new construct that is believed to moderate students' behavioural intention. The relationships between the different factors form the research hypotheses.
\end{abstract}

Keywords-Mobile learning; Mobile learning; Higher education; UTAUT; IS Success

\section{INTRODUCTION}

Knowledge acquisition is no longer restricted to a certain place and time. In fact, there is a rapid change taking place to traditional learning methods[1]. Learning in the 21st century, or the digital age, is affected by the rapid development of information and communication technologies and the availability of low-cost mobile devices[2] (mobile laptops, tablets, smart phones, PDAs, etc.), and this has resulted in mobile devices becoming more pervasive. Mobile learning is not yet well defined in the literature due to the argument regarding whether to focus on the mobility of learners or devices. Further, it is argued that mobile learning is defined from a technical perspective instead of through the consideration of pedagogical elements. Generally, mobile learning is defined as the conducting of educational activities using a mobile device and wireless service in which both learner and device are mobile[3].
For learners, a mobile-learning environment assists in accessing content quicker, allowing collaborative learning, improving communication between learners, and allowing learners to conduct study-related activities from different locations[4]. For education providers, there have been various initiatives investigating the proliferation and role of the mobility of devices and learners. Therefore, the acceptance and success of mobile Learning-systems, as they are Information Systems in nature, have drawn researchers' attention.

The main purpose of this paper is to develop a framework that assists in understanding students' behavioural intention to use mobile Learning-systems in a higher-education setting. The rest of this paper is structured as follows: First, literature reviews about previous models and theories that have been used to understand the intention and acceptance of an IS are discussed. Second, the two models used in this paper are presented, namely the Unified Theory of Acceptance and Use of Technology[5] and the DeLone and McLean model(D\&M henceforth) $[6,7]$.

Third, the research model and hypotheses development are described. The methodology section provides comprehensive details about the research instruments, constructs validation, sampling and the outline for the research method, data collection, and analysis tools are elaborated. The Data analysis and the discussion follow the methodology section where the research hypotheses were examined, and the results were discussed. This paper hopes to contribute to the work in developing a framework that can be used with students' intention to use mobile Learning-systems.

\section{ACCEPTANCE, THEORIES AND MODEL}

Reviewing the relevant literature reveals that investigating Information-System (IS) acceptance has received great attention during the last three decades. Among these models, research such as [8] cited eight models that explain human behaviour and predict IS acceptance: the Theory of Reasoned Action (TRA) [9]; then, based on TRA, Davis [10] introduced the technology acceptance model (TAM); the theory of planned behaviour (TPB) [11]; the motivational model (MM) [12]; the social cognitive theory (SCT) [13, 14]; a combination of TAM and TPB (C-TAM-TPB) [15]; the model of PC utilisation (MPCU)[16, 17]; and the innovation diffusion theory (IDT) $[18,19]$. 


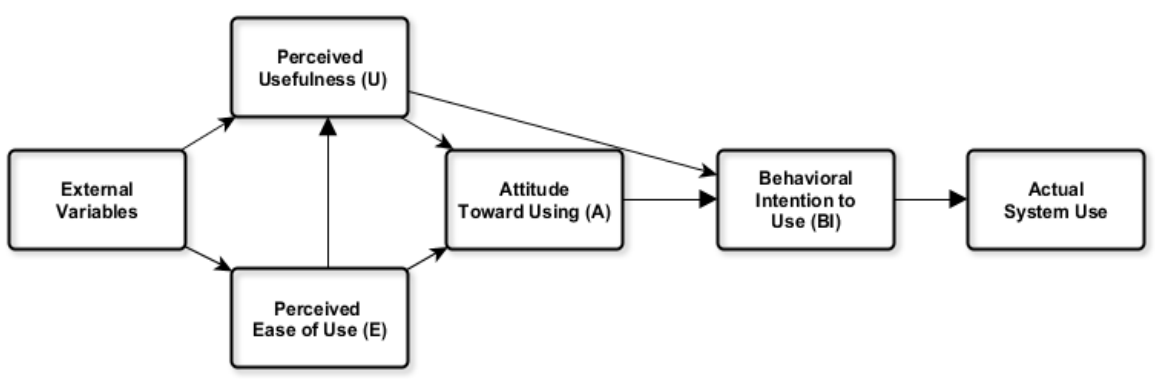

Fig.1. Technology Acceptance Model (TAM) [10]

TRA is suggested to be a fundamental theory in understanding human behaviour. In TRA, behaviour and intention are influenced by two main constructs: attitude about behaviour and subjective norms [9]. Following TRA, TAM was introduced to help understand users' acceptance and usage of a given IS[10]. In TAM, perceived ease of use and perceived usefulness are the core constructs that affect users' attitude and intention, and therefore their use of IS.

Based on a research conducted by Davis [10] the extended TAM, known as the unified theory of acceptance and use of technology (UTAUT), was introduced. UTAUT constructs are derived from the eight models mentioned above Wang, et al. [8].

In terms of measuring IS success, In their research, Wang and Shee [20] cited that the D\&M model on IS success [6, 7] appears frequently in system-success studies[21-23].

In this paper, the IS-success model and UTAUT are combined to provide the research-model construction and hypothesis formulation. Our research has two objectives. First, we suggest a framework that can be used to measure students behavioural intention to use mobile-learning systems. The second objective is to examine the relationship between the various variables and students' behavioural intention to use such systems.

In the following section, both the UTAUT and IS-success models are introduced in more detail.

\section{A. Unified Theory of Acceptance and Use of Technology}

The UTAUT [5] attempted to unify previous theories, as there was an argument about similarities in variables that predicted IS acceptance introduced within these models in different terminologies[24]. UTAUT, as shown in Fig.2, suggests that four core constructs, namely performance expectancy, effort expectancy, social influence, and facilitating conditions affect users' behavioural intention and use behaviour. It also incorporate four other variables: gender, age, experience, and voluntariness of use that [5] highlight to moderate users' adoption of an IS.

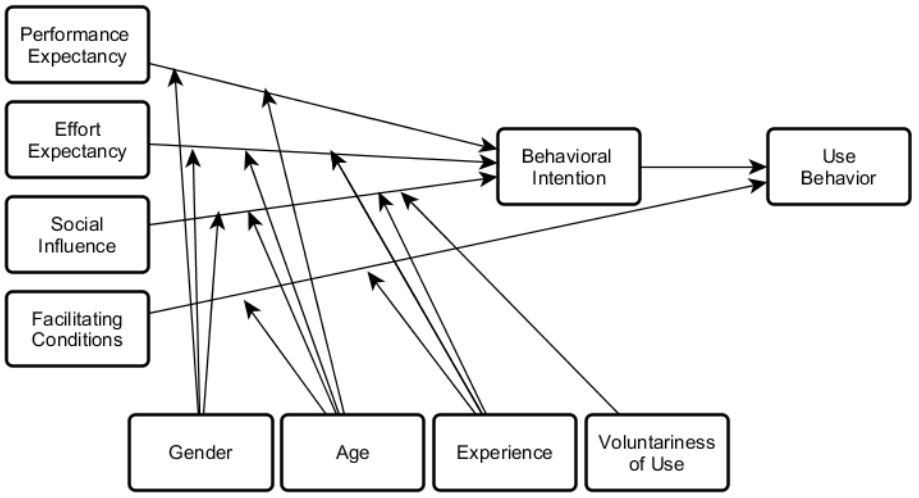

Fig.2. Unified Theory of Acceptance and Use of Technology (UTAUT)[5]

Using these eight determinants in UTAUT, it is evident from the literature that UTAUT is able to explain approximately $70 \%$ of technology acceptance behaviour $[5,25$, 26]. Further, UTAUT has received researchers' attention to empirically validate the model, and it has been successfully tested in the realm of mobile-technology adoption, which is similar to the scope of this study[27] [28] [24] [8, 26]. As shown in Fig.1. it is clear that TAM[10] provides the basis for UTAUT. The original TAM suggests that the acceptance or rejection of an IS can be measured based upon two beliefs: perceived usefulness and perceived ease of use. Perceived usefulness (PU) is defined as "the degree to which a person believes using a particular system would enhance his or her job performance" [10], and the other belief is "perceived ease of use" (PEOU), which is defined as "the degree to which a person believes that using a particular system would be free of effort" [10].

Within UTAUT, the two prominent beliefs in TAM are similar to performance expectancy and effort expectancy, respectively. The other constructs are 1) social influence, which directly affects behavioural intention to use the IS and 2) facilitating conditions, which directly impacts use behaviour. Within the current research interest and focus, the direct determinants of behavioural intention are used to avoid incorrect inference. 


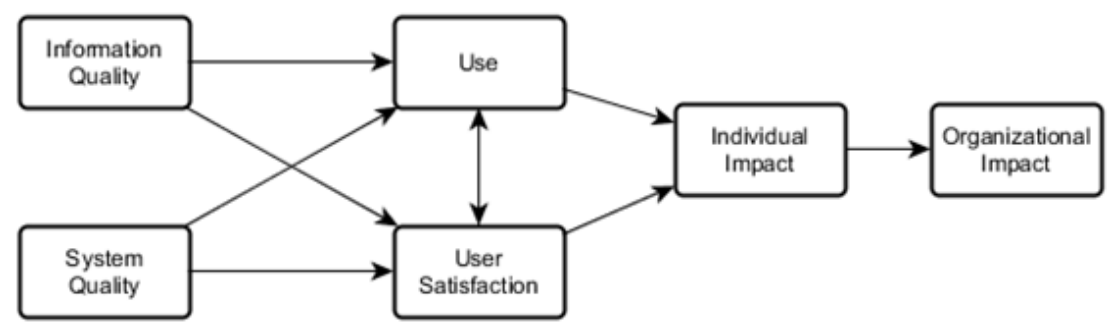

Fig.3. D\&M IS Success Model[6]

Thus, facilitating condition was eliminated from the proposed model, as it is not a direct determinate on behavioural intention to use[5]. Further, age and gender are also removed for simplicity, and the other two variables, experience and voluntariness of use, suggested by UTAUT are omitted because experience moderates user behaviour, and the current study investigates mobile learning in a voluntary-usage environment. Moreover, because the research goal is to measure students' behavioural intention to use mobile Learning-systems, the use behaviour in UTAUT[5] and use in the D\&M[6, 7] model are also eliminated.

\section{B. IS Success model}

D\&M [6] proposed a model for measuring IS success. After a comprehensive review of relevant literature regarding IS success measures, D\&M concluded that IS success can be measured using a multidimensional model that adopts six different success categories: system quality, information quality, use, user satisfaction, individual impact, and organizational impact (see Fig.3).

System quality and information quality affect use and user satisfaction. Further, user satisfaction can be affected by the amount of use and vice versa. Use and user satisfaction jointly and separately have a direct association with individual impact.

Finally, individual impact is a direct antecedent of organisational impact. Hence, the D\&M model essentially provides a multitude of IS-success measures and proposes temporal and causal interdependencies between quality characteristics (system quality); IS-output quality (information quality); output consumption (use); users' response (user satisfaction); behavioural effects of the IS on users (individual impact); and, lastly, IS effects on organisational performance (organisational impact)[29, 30]. The relationship between the six categories has been empirically investigated by many researchers (e.g., [29-32]).

In response to suggestions from the literature and evidence from empirical studies, an updated IS-success model was proposed [7]. In the updated IS-success model, DeLone and Mclean [7] introduced "service quality" as a new measurement, and both individual and organisational impacts were grouped into a new category called "net benefits" (see Fig.4).

In this research, the categories adopted from the updated IS Success model [7] are explained in the research-model section.

\section{RESEARCH MODEL}

Various types of models have been applied to the context of mobile learning in order to understand and explain students' use of mobile learning and their satisfaction about mobile Learning-systems. In a mobile-learning context, however, there is a gap in the literature with regard to providing a theoretical framework in which empirical research can be grounded[33, 34]. In addition, Sun and Zhang [35] highlight that previous theories can be further improved. Most importantly, in their research to validate D\&M model (Rai, Lang, \& Welker, [36] recommended integrating theories and developing a multiconstructs model that considers beliefs, attitude, and behaviour in addition to IS-success measures.

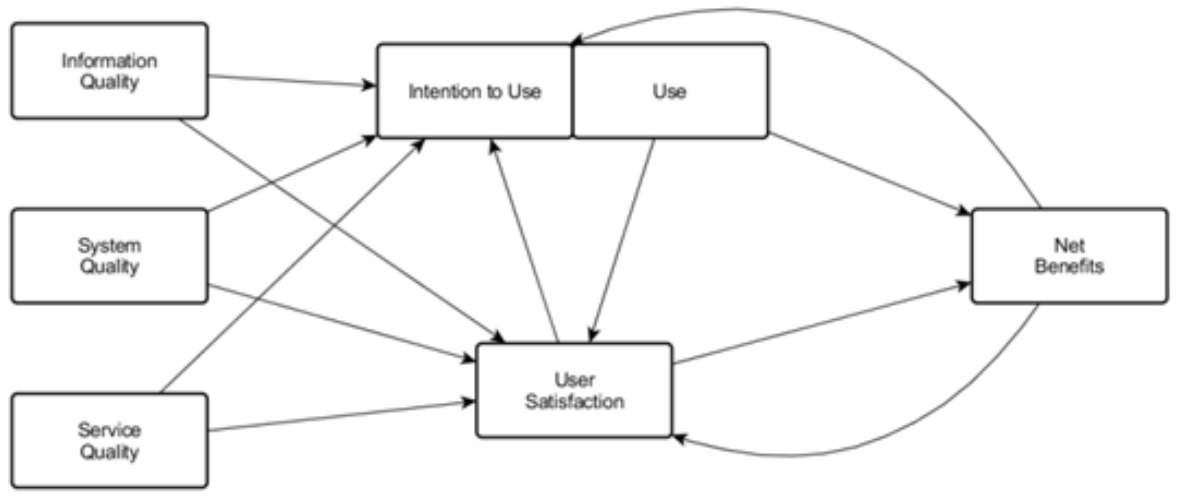

Fig.4. Updated D\&M IS Success Model[7] 
Therefore, the research model, as shown in Fig.5, in this research combines constructs from UTAUT [5] and success categories from the D\&M model[7]. And it also introduces a new moderator found in the literature of mobile and eLearning: lecturer attitude. The following subsections provide a comprehensive look at the theoretical groundwork provided by prior studies in order to formulate relevant hypotheses for this research.

\section{A. The relationship between UTAUT constructs and behavioural intention}

As discussed earlier, and in accordance with the current study objectives, the three core constructs in UTAUT have been adopted in this study. These constructs include performance expectancy, effort expectancy, and social influence. This is because they directly impact behavioural intention. However, the fourth construct, which is facilitating conditions, is eliminated from the current study due to the absence of its effect on behavioural intention[5]. Therefore, in relation to UTAUT variables, three hypotheses were introduced in this study.

\section{1) Performance expectancy}

First, performance expectancy replaced determinants found in other models (Table I). In this study, performance expectancy is defined as the "degree to which a student believes that using mobile learning systems is helpful, useful and helps him/her to do tasks quickly, and attain gain in learning outcomes". In addition, performance acceptance is a direct determinant of a user's behavioural intention to use an IS, thus it can be validated[5]. Therefore, the following is hypothesised:

a) H1: Performance expectancy would positively affect students' behaviour intention to use mobile Learning-systems.

2) Effort expectancy

Second, effort expectancy, which is also proposed in UTAUT, combines other variables (Table I). Within this study, effort expectancy is referred to as "the degree of ease associated with the use of mobile Learning-systems: the ease of using the systems, the flexibility of interaction, and interaction with mobile Learning-systems is clear and understandable". Effort expectancy is already validated to have a direct impact on a user's behavioural intention to use IS[5]. Therefore, hypotheses on the relationship between effort expectancy and behavioural intention are as follows:

a) H2: Effort expectancy would positively affect students' behaviour intention to use mobile Learning-systems.

\section{3) Social influence}

Further, the linkage between the third construct, social influence, and behavioural intention is examined. Considering the current study context, social influence is defined as the "degree to which a student perceives the importance of others believe he or she should use mobile Learning-system". Similar to the previous constructs, social influence is empirically tested to be used as a direct determinate of a user's intention to use an IS[5]. Therefore, the following is the hypotheses on the relationship between social influences and behavioural intention: a) H3: Social influence would positively affect students' behaviour intention to use mobile Learning-systems.

TABLE.I. ADAPTED FROM[5], Cited In[25]

\begin{tabular}{|l|l|l|}
\hline $\begin{array}{l}\text { UTAUT } \\
\text { Constructs }\end{array}$ & The Sub-Constructs & The source theory/ies \\
\hline \multirow{4}{*}{$\begin{array}{l}\text { Performance } \\
\text { Expectancy }\end{array}$} & Perceived Usefulness & TAM/TAM2/C-TAM-TPB \\
\cline { 2 - 3 } & Extrinsic Motivation & MM \\
\cline { 2 - 3 } & Job-Fit & MPCU \\
\cline { 2 - 3 } & Relative Advantage & IDT \\
\cline { 2 - 3 } & Outcome Expectations & SCT \\
\hline \multirow{4}{*}{ Effort Expectancy } & Perceived Ease of Use & TAM/TAM2 \\
\cline { 2 - 3 } & Complexity & MPCU \\
\cline { 2 - 3 } & Ease of Use & IDT \\
\hline \multirow{4}{*}{ Social Influence } & Subjective Norm & $\begin{array}{l}\text { TRA, TAM2, TPB/DPTB, } \\
\text { C-TAM/TPB }\end{array}$ \\
\cline { 2 - 3 } & Social Factors & MPCU \\
\cline { 2 - 3 } & Image & IDT \\
\hline
\end{tabular}

\section{B. Success measures}

Success measures vary from one IS to another. Stockdale and Borovicka [37] states that success measures are influenced by the type of system being evaluated. Thus, it is important to relate the context of the IS to the appropriate success measure[38].In this study, information and system quality are adapted from DeLone and McLean [7]. In addition, findings from Wixom and Todd [39] is discussed.

According to DeLone and McLean [6, 7], information quality is the quality of the output of the IS. It considers the completeness and whether the IS provides all relevant information. Further, information quality is measured by the format and information presentation. Accuracy and correctness of information are also included in information quality measure. Accuracy concerns data correctness; currency assess whether the information is up to date.

The other success measure in the D\&M model, system quality, measures the functionality and performance of the IS [7]. System quality considers various dimensions of the IS, such as reliability, flexibility, accessibility, and usefulness.

It has been found in the literature that validates the D\&M model[7] that information quality and system quality jointly or separately affect user satisfaction - the user's response to the IS[40-42]. Consequently, user satisfaction also affect the user's intention to use the IS[6,7].

Therefore, based on the discussion above, the following is hypothesised:

a) H4: Information quality would positively affect students' satisfaction about mobile Learning-systems.

b) H5: System quality would positively affect students' satisfaction about mobile Learning-systems.

c) H6: Students' satisfaction would positively affect students' intention to use mobile Learning-systems. 


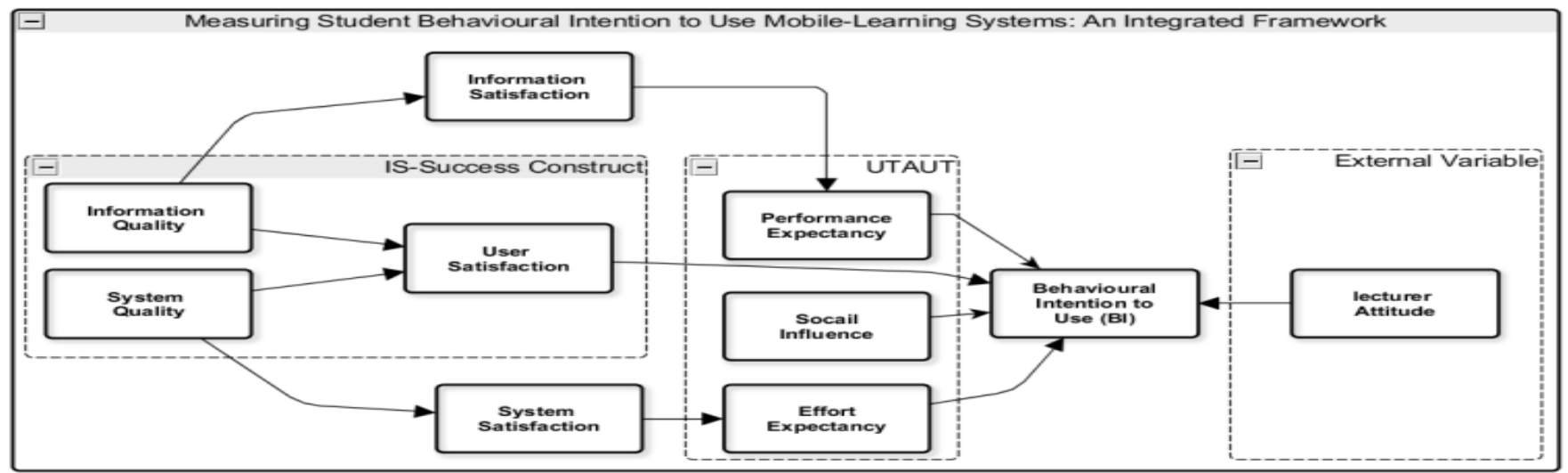

Fig.5. The research model

Further, Seddon and Kiew[40] revised the D\&M model and replaced use with usefulness. The authors concluded that system usefulness positively impacts the actual use. However, not using the system does not automatically mean it is not useful. In addition, in a research on theoretical integration of user satisfaction and technology acceptance, Wixom and Todd [39] introduced two measures: information satisfaction and system satisfaction. The former measures the satisfaction with information produced by the system. The latter addresses the degree of favourableness with regard to the system and interaction mechanism. In their conclusion, the authors highlight that information and system satisfaction are directly affected by information and system quality, respectively. In addition, the more information satisfaction, the more likely one will find the IS useful. In the same vein, the more system satisfaction, the more likely one will find an IS easy to use. It is noteworthy that usefulness and ease of use are the main constructs in TAM. However, as UTAUT is employed in this study instead of TAM, the performance expectancy and effort expectancy are used. They capture usefulness and ease of use, respectively[5].

Therefore, the discussion above led to the following hypothesis:

d) H7: Information quality would positively affect information satisfaction of mobile Learning-systems.

e) H8: System quality would positively affect system satisfaction of mobile Learning-systems.

f)H9: Information satisfaction would positively affect performance expectancy.

g) H10: System satisfaction would positively affect effort expectancy.

\section{The relationship between the introduced construct and behavioural intention}

In a study of acceptance of mobile learning, Wang, et al. [8] highlights that the mobile-learning context is not necessarily similar to other IS, and therefore UTAUT core constructs may not be sufficient in determining a user's behavioural intention. Further, Pedersen and Ling [43] , as cited in Wang, et al.,[8], suggest to modify existing models in order to apply them to mobile Internet services, including mobile learning. Therefore, an additional construct was incorporated in this study: lecturer attitude.

\section{1) Lecturer's attitude}

Very little research focuses on addressing the impact of instructors' opinions on students' behavioural intention to use mobile devices in learning. Researchers such as Brubaker [44] investigated instructors' attitudes towards using laptop devices during lectures; the result reveals that a majority of respondents emphasise that laptops distract students. A recent study on students' perceptions confirms the finding. The recent qualitative study by Gikas and Grant [45] reflects that students are frustrated because of anti-technology instructors who are unwilling to incorporate technology into their courses. By contrast, Alsaggaf, et al. [46] studied faculty perception in using mobile devices in their classes, and the result showed that lecturers may have a positive believe on students using mobile devices. Therefore, from the discussion above, researchers believe that lecturers' attitudes could affect students' behavioural intention to use mobile Learningsystems. Hence, the following is hypothesised:

a) H11: Lecturers' attitude toward using mobile devices would positively affect students' behavioural intention to use mobile Learning-systems.

\section{Methodology}

A quantitative empirical method is used to validate the research model. From a methodological point of view, a survey is used within this research to accomplish the study objectives[47, 48].First, this study is based on well-tested and validated research instruments in previous similar researches. Further, this study objectively investigates the relationships between various constructs, therefore using survey as method for data collection enables testing the research hypotheses. The necessary data for the model validation is collected using an online survey. Online surveys provide researchers with various benefits[49], including saving researchers time and reducing expenses by overcoming geographic distance. Further, online surveys enable recruiting unique subjects.

Further explanation and verification of the model constructs will be undertaken. The development of the scale will be based on previously-validated scales available from relevant 
literature. Specifically, the questionnaire will be constructed from the original UTAUT model[5] and IS success model[6, 7]. Further, for other measures proposed by authors, experts from the mobile-learning field were contacted to ensure content validity. The participants in this research will be undergraduate and postgraduate students from different faculties and disciplines. Participants will be recruited by emailing the URL to the questionnaire. A probability-sampling technique, particularly random sampling, is utilized in this study to achieve the sample frame. Random sampling is used when each unity in the population has the chance to participate[50]. SPSS software package is used to accomplish proper statistical processing and therefore determine significant relationships between the different variables within the research model.

\section{A. Survey population}

Participants in this project were any person enrolled in any undergraduate or postgraduate degree at Griffith University, Australia. The potential participant pool includes students from any level of study and including on-campus and offcampus students. That includes those who are currently doing their English course at Griffith English Language Centre. Participants were recruited by word of mouth, and via email during which official calls for participation were issued.

\section{B. Instrument development}

To ensure content validity, the questionnaire used in this study was adapted from the original measurement scales used in UTAUT model[5], IS success model[6, 7], Modified IS Success[40], and on the basis of literature review, the lectures' attitude is added as a new construct. The necessary modifications and wording changes and validation was made to fit the context of mobile learning context. To avoid issues that can occur in wordings, measurement and ambiguities, the questionnaire was pre-tested by two native English speakers. Sekaran and Bougie [51] highlight that such pre-test is essential because wording problems significantly influence accuracy[52].

The research instrument consists of five main sections. The first section incorporates a nominal scale to identify respondents' demographic information. The second section to the fifth section uses 7-point Likert response scale where 7: Strongly agree, 6: Moderately agree, 5: Slightly agree, 4: Neutral, 3: Slightly disagree, 2: Moderately disagree, and 1: Strongly disagree.

The second section concerns UTAUT constructs. IS Success items are presented in the third section. The fourth section consists of the Modified IS Success variables. Finally, the introduced variables, lecturer's attitude is included in the fifth section. The sections from two to five are presented in the Table 2 below with the subsections for each model. The full questioner, including the demographics information is available in Appendix A.
TABLE.II. RESEARCH INSTRUMENTS

Mobile Learning-system usage: An integrated framework to measure students' behavioural intention

Scales and items

2. UTAUT(adapted from Venkatesh, Morris, Davis, \& Davis (2003))

\begin{tabular}{|c|c|}
\hline \hline Section I & Performance Expectancy \\
\hline \hline
\end{tabular}

\begin{tabular}{|l|l|}
\hline \hline PEE1 & I feel that mobile learning is useful. \\
\hline
\end{tabular}

\begin{tabular}{|l|l}
\hline PEE2 & Mobile learning improves my study efficiency. \\
\hline
\end{tabular}

\begin{tabular}{l|l}
\hline PEE3 & Mobile learning improves my study convenience.
\end{tabular}

\begin{tabular}{ll|l}
\hline PEE4 & Mobile learning lets me do study related tasks more quickly.
\end{tabular} \begin{tabular}{|c|r|}
\hline Section I & Effort Expectancy \\
\hline
\end{tabular}

\begin{tabular}{|l|l|}
\hline EFE1 & Skilfully using mobile learning is easy for me.
\end{tabular}

\begin{tabular}{|l|l|}
\hline EFE2 & I find that using mobile learning is easy. \\
\hline EFE3 & Learning how to use mobile learning is easy for me. \\
\hline EFE4 & My interaction with mobile learning is clear and understandable.
\end{tabular}

\begin{tabular}{l|l} 
EFE4 & My interaction with mobile learning is clear and understandable.
\end{tabular} Section III $\quad$ Social Influence

\begin{tabular}{|l|l|}
\hline SOI1 & Those people that influence my behaviour think that I \\
\hline
\end{tabular} \begin{tabular}{|l|l|} 
SOI1 & $\begin{array}{l}\text { Those people that influence } \\
\text { should use mobile learning }\end{array}$ \\
\hline
\end{tabular} \begin{tabular}{l|l} 
SOI2 & $\begin{array}{l}\text { Those people that are important to me think that I should use } \\
\text { mobile learning }\end{array}$
\end{tabular}

\begin{tabular}{|l|l|l|}
\hline \hline \multicolumn{2}{|c|}{ Section IV } & \multicolumn{1}{c|}{ Behavioural Intention to Use } \\
\hline \hline BI1 & I intend to use the mobile learning system in the future \\
\hline BI2 & I predict I would use the mobile learning system in the future \\
\hline BI3 & I plan to use the mobile learning system in the future \\
\hline \hline
\end{tabular}

3. IS Success (adapted from DeLone \& McLean (1992,2003))

Section I $\quad$ Information Quality

\begin{tabular}{|l|l}
\hline \hline IQ1 & The mobile learning system provides information that is exactly
\end{tabular} \begin{tabular}{|l|l|}
\hline IQ2 & $\begin{array}{l}\text { That you need (Content Accuracy) } \\
\text { right time (Availability) }\end{array}$ \\
\hline
\end{tabular}

\begin{tabular}{|l|l|}
\hline IQ3 & The mobile learning system provides information that is relevant to
\end{tabular} \begin{tabular}{|l|l} 
& your course (Usability, relevance) \\
\hline IQ4 & The mobile learning system provides sufficient information for
\end{tabular} \begin{tabular}{l|l} 
IQ4 & $\begin{array}{l}\text { The mobile learning system provides suffic } \\
\text { your purposes (Quantity of information) }\end{array}$ \\
\hline
\end{tabular}

\begin{tabular}{l|l} 
IQ5 & The mobile learning system provides information that is easy to
\end{tabular} \begin{tabular}{|l|l} 
& understand (Understandability) \\
\hline IQ6 & The mobile learning system provides up-to-date information \\
(Cur
\end{tabular}

\begin{tabular}{l|l} 
IQ6 & (Currency) \\
\hline IQ7 & The mobile learning system provides information that appears
\end{tabular}

\begin{tabular}{l|l} 
IQ7 & $\begin{array}{l}\text { The mobile learning system provides information } \\
\text { readable, clear and well formatted (User interface) }\end{array}$ \\
\hline
\end{tabular}

\begin{tabular}{|l|l|}
\hline IQ8 & The mobile learning system provides required information on time.
\end{tabular}

\begin{tabular}{l|l}
\hline IQ9 & The mobile learning system provides information that is suitably
\end{tabular} concise.

\begin{tabular}{|l|l|}
\hline \hline \multicolumn{2}{|c|}{ Section II } \\
\hline \hline SQ1 & $\begin{array}{l}\text { The mobile learning system allows a high level of customization } \\
\text { for different courses }\end{array}$ \\
\hline SQ2 & $\begin{array}{l}\text { The mobile learning system provides for personalized information } \\
\text { presentation }\end{array}$ \\
\hline SQ3 & The mobile learning system is easy to use \\
\hline SQ4 & The mobile learning system is user-friendly (Easy to learn) \\
\hline SQ5 & $\begin{array}{l}\text { The mobile learning system provides a high of availability } \\
\text { (Access) }\end{array}$ \\
\hline SQ6 & $\begin{array}{l}\text { The mobile learning system provides an appropriate level of on- } \\
\text { line assistance and explanation (User requirements) }\end{array}$ \\
\hline SQ7 & $\begin{array}{l}\text { The mobile learning system provides interactive features for an } \\
\text { effective user experience }\end{array}$ \\
\hline
\end{tabular}


(IJARAI) International Journal of Advanced Research in Artificial Intelligence,

Vol. 3, No.11, 2014

Extended Paper from Science and Information Conference 2014

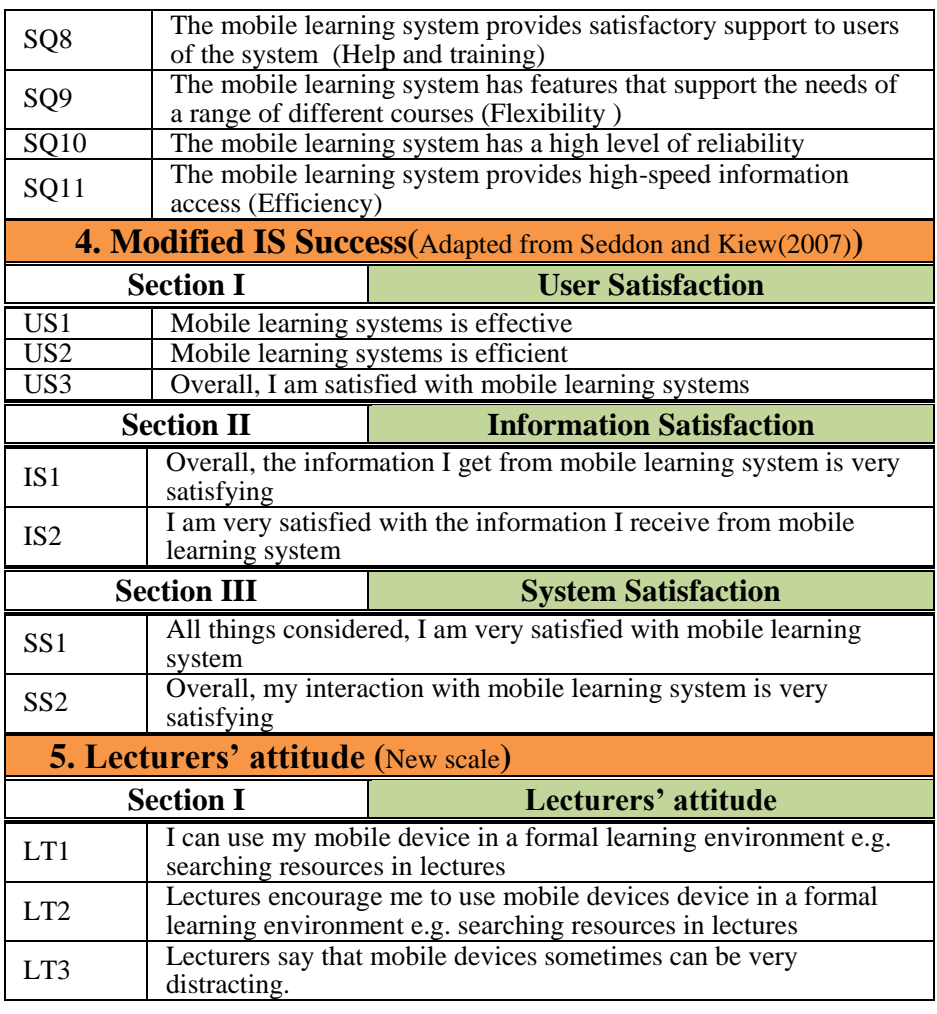

\section{Data Collection}

The questionnaire was made available at the first semester of the academic year 2014. The survey was distributed online by emailing the potential population the URL to the survey. At this time, 204 responses were recorded. Of that, only 124 responses yielded valid responses that were used for analysis.

\section{Reliability}

Reliability assessment was done using Cornbach Alpha[53]. Reliability concerns internal consistency between multiple measurements of variables, and Cornbach Alpha is commonly used to measure it[54]. As per many studies(i.e.,[55, 56], constructs are considered to have internal consistency reliability when the Cronbach Alpha value exceeds 0.07.

In this study, the reliability assessment was done using Statistical Package for Social Sciences (SPSS) version 22. All measures in this study show a high level of reliability, ranging from 0.924 to 0.981 . All scales exceeded 0.70, and therefore the survey is considered reliable. However, the new introduced scale, lecturer attitude shows a low reliability score of .63 which suggest that this construct needs further revision. Further, according to De Vaus [57] reliability score might be attributed to the smaller number of items. The table below (Table III) summaries the reliability analysis for all constructs. The overall reliability for all scales exceeded 0.70 , and therefore the survey is considered reliable.
TABLE.III. RELIABILITY ANALYSIS

\begin{tabular}{|l|l|l|}
\hline Scale & $\begin{array}{l}\text { Number } \\
\text { of Items }\end{array}$ & Cronbach Alpha \\
\hline Performance Expectancy (PEE) & 4 & 0.924 \\
\hline Effort expectancy (EFE) & 6 & 0.960 \\
\hline Social Influence (SOI) & 2 & 0.958 \\
\hline Behavioural intention to use (BIU) & 3 & 0.973 \\
\hline Information Quality(IQ) & 9 & 0.958 \\
\hline System Quality(SQ) & 11 & 0.963 \\
\hline User Satisfaction (US) & 3 & .958 \\
\hline Information Satisfaction (IS) & 2 & .960 \\
\hline System Satisfaction (SS) & 2 & .981 \\
\hline Lecturer Attitude (LT) & 3 & .63 \\
\hline Overall reliability & 43 & 0.98 \\
\hline
\end{tabular}

\section{E. Ethics}

This research is being conducted in accordance with the ethics requirements by the relevant research ethics committee. Prior to the commencement of the data collection stage, ethical approval was obtained. Before commencing the survey, a full disclosure of the research title, purpose, expected benefits, and the ethical conducts of the research was provided to all participants. Further, participants were made aware of the voluntary participation in which they do not have to answer every question unless they wish do so, and they may withdraw at any stage of the questionnaire. In addition, data was collected anonymously and no personal information about the subjects were collected. The confidentiality of the data collected was assured to all participants. Finally, participants were provided with the researchers' information and contact details, and the research ethics committee contact details for any inquiry.

\section{DATA ANALYSIS}

\section{A. Demographics}

Most of the participants were female, $77 \%$ females and 32 females. The majority of participants were between 18 and 24 years, with $50.81 \%$ from 18 to $24,24.19 \%$ from 25 to 34 , $13.71 \%$ from 35 to 44 , and $11.29 \%$ range from 17 to 18 , and above 44 . The rest of demographic information regarding the level of education, device types, the various use of mobile devices, and the use of Griffith mobile app are presented in the figure presented in the next page (Fig. 6).

\section{B. Statistical analysis and hypotheses testing}

In line with the study objective, correlation analysis was conducted to examine the relationship between the variables used within this study, and therefore to empirically decide whether or not to accept or reject the null hypotheses. The strength of correlation coefficients is determined based on the categorisation proposed by Dancey and Reidy [58] as follows: a)perfect correlation(1), b) Strong (0.7-0.9), c) Moderate(0.4$0.6)$, d) Weak(0.1-0.3), e) Zero(0). 
Hypotheses on the relationship between UTAU constructs and behavioural intention are presented first.

1) The relationship between UTAUT constructs and behavioural intention

a) H1: Performance expectancy would positively affect students' behaviour intention to use mobile Learning-systems.

The correlation analysis result in Table IV below shows that there is a strong positive relationship between $\mathrm{PE}$ and BIU and this correlation is significant, $\mathrm{r}(124)=.828, \mathrm{p}<.005$. This correlation suggests that when performance expectancy increases, students' behavioural intention to use mobilelearning systems will increase. Hence, $\mathrm{H} 1$ is supported.

TABLE.IV. PE AND BIU CORRELATIONS

\begin{tabular}{|c|c|}
\hline \multicolumn{2}{c|}{ Correlations } \\
Factors \\
revalue \\
p-value \\
$\mathrm{N}$
\end{tabular}

PE: Performance expectancy; BIU: Behavioural intention to use

b) H2: Effort expectancy would positively affect students' behaviour intention to use mobile Learning-systems.

The correlation analysis result in Table $\mathrm{V}$ below shows that there is a fairly strong positive and significant relationship between EF and BIU, $\mathrm{r}(124)=.664, \mathrm{p}<.005$. This correlation suggests that when effort expectancy increases, students' behavioural intention to use mobile-learning systems will increase. Hence, $\mathrm{H} 2$ is supported.

TABLE.V. EF AND BIU CORRELATIONS

\begin{tabular}{|c|c|c|}
\hline \multicolumn{2}{|c|}{ Correlations } \\
\hline \multirow{4}{*}{ EF } & Factors & BIU \\
\hline & r-value & $.664 * *$ \\
\hline p-value & .000 \\
\hline $\mathrm{N}$ & 124 \\
\hline
\end{tabular}

EF: Effort expectancy; BIU: Behavioural intention to use

c) Social influence would positively affect students' behaviour intention to use mobile Learning-systems.

The correlation analysis result in Table VI below shows that there is a fairly a weak positive relationship between SOI and BIU, $r(124)=.323, p<.005$. Since the correlation is significant, $\mathrm{H} 3$ is statistically supported.

TABLE.VI. SOI AND BIU CORRELATIONS

\begin{tabular}{|c|c|c|}
\hline \multicolumn{3}{|c|}{ Correlations } \\
\hline \multicolumn{2}{|c|}{ Factors } & BIU \\
\hline \multirow{3}{*}{ SOI } & r-value & $.323^{\circ}$ \\
\hline & p-value & .000 \\
\hline & $\mathrm{N}$ & 124 \\
\hline \multicolumn{3}{|c|}{ SOI: Social influence; BIU: Behavioural intention to use } \\
\hline
\end{tabular}

2) The relationship between Success measures constructs and behavioural intention

a) H4: Information quality would positively affect students' satisfaction about mobile Learning-systems.

The correlation analysis result in Table VII below shows that there is a fairly strong positive and significant relationship between IQ and SS, r $(124)=.870, \mathrm{p}<.005$. This correlation suggests that when information quality increases, students' satisfaction about mobile-learning systems will increase. Hence, H4 is supported.

TABLE.VII. IQ AND SS CORRELATIONS

\begin{tabular}{|c|c|c|}
\hline \multicolumn{3}{|c|}{ Correlations } \\
\hline \multirow{4}{*}{ Factors } & SS \\
\hline IQ & r-value & $.870^{-*}$ \\
& p-value & .000 \\
\hline IQ: Information Quality; SS: System Satisfaction \\
\hline
\end{tabular}

3) The relationship between Success measures constructs and behavioural intention

a) H4: Information quality would positively affect students' satisfaction about mobile Learning-systems.

The correlation analysis result in Table VII below shows that there is a fairly strong positive and significant relationship between IQ and SS, $\mathrm{r}(124)=.870, \mathrm{p}<.005$. This correlation suggests that when information quality increases, students' satisfaction about mobile-learning systems will increase. Hence, H4 is supported.

TABLE.VIII. IQ AND SS CORRELATIONS

\begin{tabular}{|c|c|c|}
\hline \multicolumn{3}{|c|}{ Correlations } \\
\hline & Factors & SS \\
\hline & r-value & .870 \\
IQ & $\mathrm{p}$-value & .000 \\
& $\mathrm{~N}$ & 124 \\
\hline IQ: Information Quality; SS: System Satisfaction \\
\hline
\end{tabular}

b) H5: System quality would positively affect students' satisfaction about mobile Learning-systems.

The correlation analysis result in Table VIII below shows that there is a strong positive and significant relationship between IQ and US, $\mathrm{r}(124)=.825, \mathrm{p}<.005$. This correlation suggests that when system quality increases, students' satisfaction about mobile-learning systems will increase. Hence, H5 is supported.

TABLE.IX. SQ AND BIU CORRELATIONS

\begin{tabular}{|c|c|c|}
\hline \multicolumn{3}{|c|}{ Correlations } \\
\hline & ors & US \\
\hline \multirow{3}{*}{ SQ } & r-value & .825 \\
\hline & $\mathrm{p}$-value & .000 \\
\hline & $\mathrm{N}$ & 124 \\
\hline
\end{tabular}




\section{Gender}

Male Female

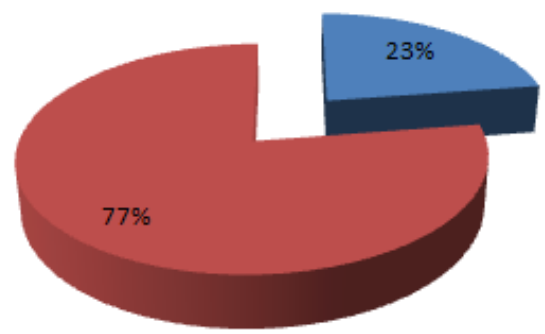

Mobile device type

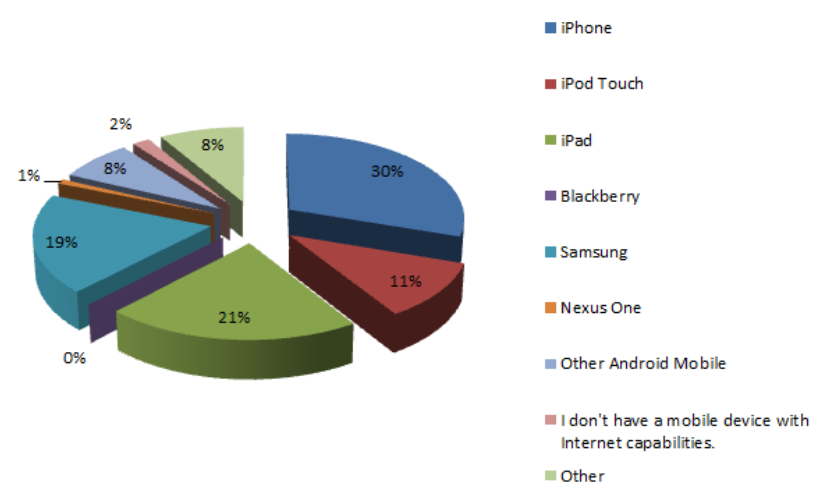

Usage of mobile device for reading content
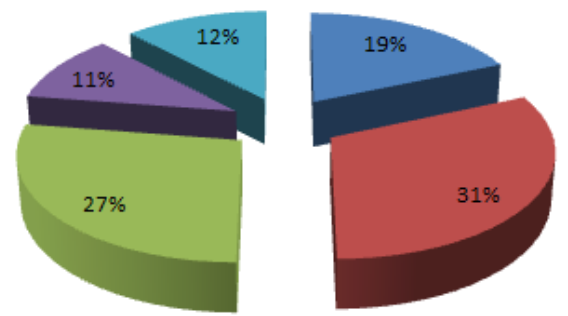

Always

- Frequently

Occasionally

narely

Never

\section{Using mobile device for completing} study related tasks

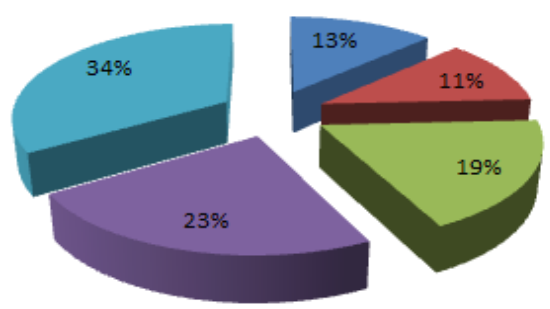

Elways

- Frequently

- Occasionally

- Rarely

never
Level of education

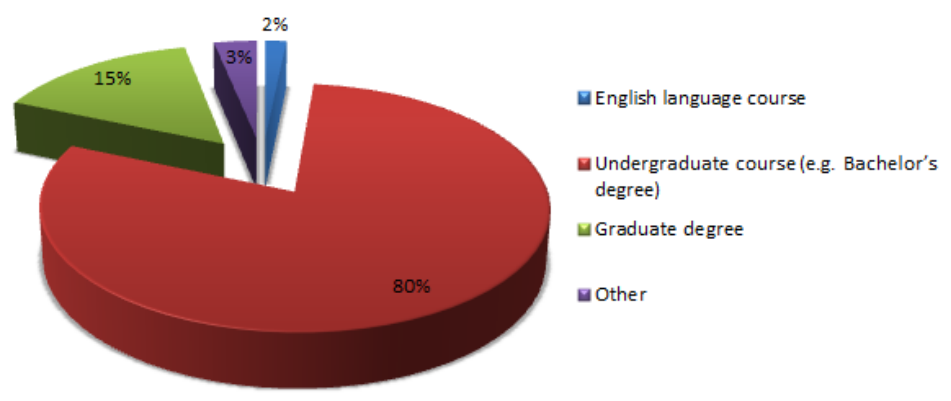

\section{Usage of mobile device for social netwroking}
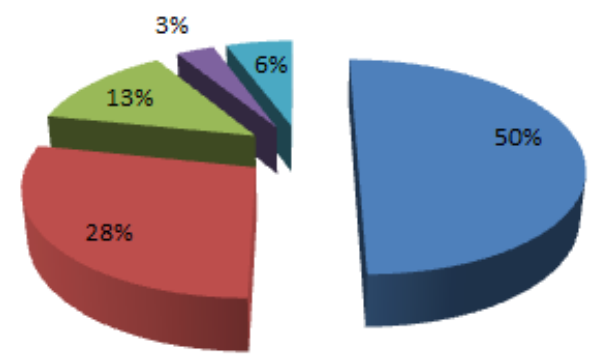

Always

- Frequently

- Occasionally

narely

never

\section{Usage of mobile device for searching for information}

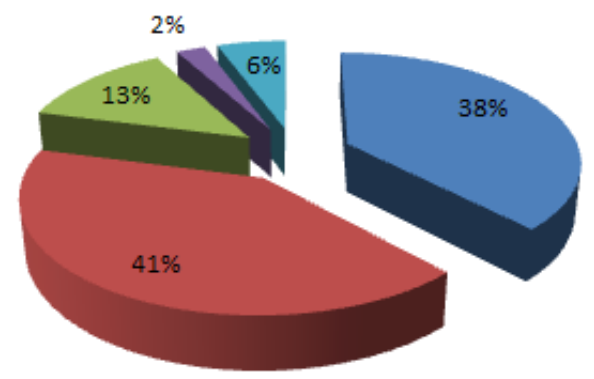

Always

arequently

accasionally

narely

Never

\section{Installed Griffith Mobile Application}
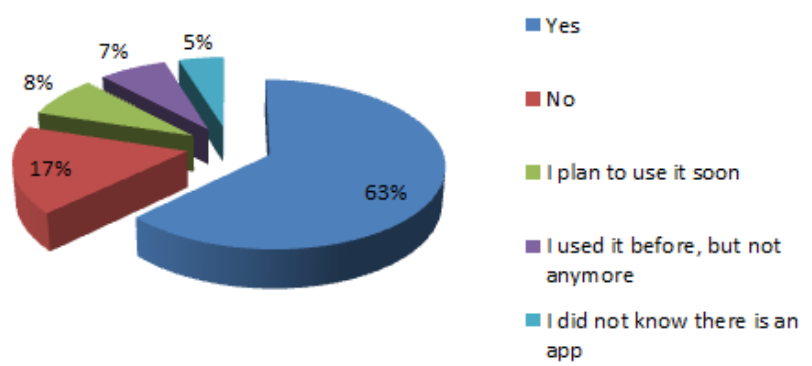

Fig.6. Respondants demographics 
c) H6: Students' satisfaction would positively affect students' intention to use mobile Learning-systems.

The correlation analysis result in Table IX below shows that there is a fairly strong positive and significant relationship between SS and BIU, $r(124)=.686, p<.005$. This correlation indicates that students' satisfaction about mobile-learning systems will increase students' behavioural intention to use mobile-learning systems. Hence, H6 is supported.

TABLE.X. SS AND BIU CORRELATIONS

\begin{tabular}{|c|c|c|}
\hline \multicolumn{3}{c|}{ Correlations } \\
\hline \multirow{3}{*}{ SS } & Factors & BIU \\
\hline & r-value & .686 \\
\hline & p-value & .000 \\
\hline $\mathrm{N}$ & 124 \\
\hline
\end{tabular}

SS: System Satisfaction; BIU: Behavioural intention to use

d) H7: Information quality would positively affect information satisfaction of mobile Learning-systems.

The correlation analysis result in Table $\mathrm{X}$ below shows that there is a fairly strong positive and significant relationship between IQ and IS, $\mathrm{r}(124)=.847, \mathrm{p}<.005$. This correlation suggests that when information quality increases, information satisfaction of mobile-learning systems will increase. Hence, $\mathrm{H} 7$ is supported.

TABLE.XI. IQ AND IS CORRELATIONS

\begin{tabular}{|c|c|c|}
\hline \multicolumn{2}{|c|}{ Correlations } \\
\hline \multirow{3}{*}{ Factors } & IS \\
\hline IQ & r-value & $.847^{*}$ \\
\hline & p-value & .000 \\
\hline $\mathrm{N}$ & 124 \\
\hline
\end{tabular}

IQ: Information Quality; IS: Information Satisfaction

e) H8: System quality would positively affect system satisfaction of mobile Learning-systems.

The correlation analysis result in Table XI below shows that there is a strong positive and significant relationship between SQ and SS, $\mathrm{r}(124)=.835, \mathrm{p}<.005$. This correlation suggests that when system quality increases, students' satisfaction of mobile-learning systems will increase. Hence, $\mathrm{H} 8$ is supported.

TABLE.XII. SQ AND SS CORRELATIONS

\begin{tabular}{|c|c|}
\hline \multicolumn{2}{c|}{ Correlations } \\
\hline Factors & SS \\
\hline SQ & .835 \\
\hline & r-value \\
\hline p-value & .000 \\
\hline SQ: System Quality; SS: System Satisfaction
\end{tabular}

f)H9: Information satisfaction would positively affect performance expectancy.

The correlation analysis result in Table XII below shows that there is a strong positive and significant relationship between IS and PE, $\mathrm{r}(124)=.745, \mathrm{p}<.005$. This correlation suggests that when information satisfaction increases, students' performance expectancy will increase. Hence, H9 is supported.

TABLE.XIII. IS AND PE CORRELATIONS

\begin{tabular}{|c|c|c|}
\hline \multicolumn{2}{|c|}{ Correlations } \\
\hline \multirow{3}{*}{ Factors } & PE \\
\hline r-value & $.745^{-*}$ \\
\hline p-value & .000 \\
\hline $\mathrm{N}$ & 124 \\
\hline
\end{tabular}

IS: Information Satisfaction; PE: Performance expectancy

g) H10: System satisfaction would positively affect effort expectancy.

The correlation analysis result in Table XIII shows that there is a strong positive and significant relationship between SS and EF, $r(124)=.745, p<.005$. This correlation suggests that when system satisfaction increases, students' effort expectancy will increase. Hence, H10 is supported.

TABLE.XIV. SS AND EF CORRELATIONS

\begin{tabular}{|c|c|c|}
\hline \multicolumn{3}{|c|}{ Correlations } \\
\hline & & $\mathrm{EF}$ \\
\hline \multirow{3}{*}{ SS } & r-value & .708 \\
\hline & $\mathrm{p}$-value & .000 \\
\hline & $\mathrm{N}$ & 124 \\
\hline
\end{tabular}

4) The relationship between lecturer attitude constructs and behavioural intention

a) H11: Lecturers' attitude toward using mobile devices would positively or negatively affect students' behavioural intention to use mobile Learning-systems.

The correlation analysis result in Table XIV below shows that there is a fairly a weak positive relationship between LT and BIU, $r(124)=.312, p<.005$. Since the correlation is significant, H11 is statistically supported.

TABLE.XV. LT AND BIU CORRELATIONS

\begin{tabular}{|c|c|c|}
\hline \multicolumn{2}{|c|}{ Correlations } \\
\hline & Factors & BIU \\
\hline \multirow{4}{*}{ LT } & r-value & .323 \\
\hline p-value & .000 \\
\hline $\mathrm{N}$ & 124 \\
\hline
\end{tabular}

LT: Lecturer attitude; BIU: Behavioural intention to use

The table below summarise the hypothesis after the testing was done.

\section{TABLE.XVI. HYPOTHESIS SUMMARY}

\begin{tabular}{|c|l|c|} 
No. & \multicolumn{1}{c|}{ Statement } & Result \\
H1 & $\begin{array}{l}\text { Performance expectancy would positively affect } \\
\text { students' behaviour intention to use mobile Learning- } \\
\text { systems }\end{array}$ & Supported \\
H2 & $\begin{array}{l}\text { Effort expectancy would positively affect students' } \\
\text { behaviour intention to use mobile Learning-systems } \\
\text { H3 }\end{array}$ & $\begin{array}{l}\text { Social influence would positively affect students' } \\
\text { behaviour intention to use mobile Learning-systems }\end{array}$ \\
\hline$\cdots \cdots \cdots \cdots$
\end{tabular}




\begin{tabular}{|c|l|c|}
$\mathrm{H} 4$ & $\begin{array}{l}\text { System quality would positively affect students' } \\
\text { satisfaction about mobile Learning-systems }\end{array}$ & Supported \\
$\mathrm{H} 5$ & $\begin{array}{l}\text { Information quality would positively affect students' } \\
\text { satisfaction about mobile Learning-systems }\end{array}$ & Supported \\
$\mathrm{H} 6$ & $\begin{array}{l}\text { Students' satisfaction would positively affect students' } \\
\text { intention to use mobile Learning-systems }\end{array}$ & Supported \\
H7 & $\begin{array}{l}\text { Information quality would positively affect information } \\
\text { satisfaction of mobile Learning-systems }\end{array}$ & Supported \\
H8 & $\begin{array}{l}\text { System quality would positively affect system } \\
\text { satisfaction of mobile Learning-systems }\end{array}$ & Supported \\
\hline H9 & $\begin{array}{l}\text { Information satisfaction would positively affect } \\
\text { performance expectancy }\end{array}$ & Supported \\
H10 & $\begin{array}{l}\text { System satisfaction would positively affect effort } \\
\text { expectancy }\end{array}$ \\
\hline H11 & $\begin{array}{l}\text { Lecturers' attitude toward using mobile devices would } \\
\text { positively affect students' behavioral intention to use } \\
\text { mobile Learning-systems }\end{array}$ & Supported \\
\hline
\end{tabular}

\section{DISCUSSION}

The current study combines well-known theories that have been used in similar researches. Research model employ constructs found in UTAUT, IS Success, Modified IS Success, and other relevant literature.

In general, the statistical analysis shows that the findings of the current study are consistent with the original theories findings [5, 7, 40, 44-46]. All constructs within this study were proven to have positive correlations that are statistically significant. Overall, the analysis shows that students behavioural intention to use a mobile learning system is greatly affected by their effort expectancy and performance eexpectancy, information and system satisfaction, information and system quality. Additionally, with less effectiveness, lecturer attitude and social influences are less likely to influence one's behavioural intention. The findings suggest that all previously mentioned variables can positively influence students' behavioural intention to use mobile-learning systems. Noticeably, the relationship between performance expectancy and behavioural intention to use is stronger than the relationship between effort expectancy and behavioural intention. It is also noteworthy to mention that a large percentage of respondents were female. Hence further investigation on the gender effect would lead to further findings.

In Summary, the statistical analysis proves the ability of the proposed research model to measure the behavioural intention of students to use mobile-learning systems. Additionally, revision and further testing is required to validate the effect of lecturers' attitudes on students' behavioural intention.

\section{CONCLUSION}

This study has explored acceptance theories and success models and their usage in mobile-learning context in highereducation. Despite the wide spread of mobile Learning-systems adoption, It has been noticed that there is a lack in investigating student behavioural intention to use such systems. Therefore this study proposes an integrated framework to measure student behavioural intention to use mobile Learning-systems. This framework combines an acceptance theory (UTAUT), and an IS-Success model (D\&M). Constructs adapted from
UTAUT are: 1) performance expectancy, 2) effort expectancy, and 3) social influences. Further, constructs adapted from D\&M model are: information quality, 2) system quality, and 3) system satisfaction. Moreover, two additional constructs were found in the literature, namely, information satisfaction and system satisfaction. In addition, lecturers' attitude is introduced in this research. The research model was validated using a questioner distributed to university students via online survey. The necessary steps were undertaking to ensure content validity and reliability of the research instruments. The data were collected and analysis using SPSS to investigate the relationships proposed in the research hypotheses. The overall results confirms the findings found in similar literature, and shows a strong and positive correlations between the various study constructs and students' behavioural intention to use mobile-learning systems. Overall, students tend to develop a positive behavioural intention to use mobile-learning systems. Students believe that behavioural intention to use mobilelearning systems is greatly affected by the perception of its ease of use and usefulness. Additionally, Information and system quality are also important factors that improve students' behavioural intention by increasing students' satisfaction about information and system quality. In contrast, the results show that social influence and lecturers' attitude toward using mobile devices during lectures are less likely to hinder students from developing a positive behavioural intention.

The research findings are valuable for paving the future of assessing students' behavioural intention to use mobilelearning systems. However, the limitation of the current study should be noted. The following subsection describes some of the limitations and provides suggestions for future improvements.

\section{A. Research limitations and future work}

There are various limitations to this study. First, is the limited ability to generalise the findings. Online survey was employed in this study, and online surveys are not free of limitations[59]. The lack of personal contact with respondent may affect the response rate in web-based surveys more than in other type of surveys[60]. In addition, a higher sample size would lead to make the conclusion more general.

Further research may investigate the role of other variables, including users' characteristics, and adding more variables to the original constructs found in the models used for this research. A systematic research may also extend this exploratory study.

In addition, several other statistical tests including factor analysis, multiple regressions, and structural equation modelling, etc. could be conducted to confirm variables' validity. Those approaches were beyond the current study scope; however it remains an area of interest for a future research.

Finally, the research model is subject to further modification. The preliminary analysis shows that further validation and investigation may reveal other factors in the context of mobile-learning systems. 


\section{REFERENCES}

[1] K. A. Marold, G. Larsen, and A. Moreno, "Web-based learning: is it working? A comparison of student performance and achievement in web-based courses and their in-classroom counterparts," in IRMA Conference, 2000, pp. 350-353.

[2] R. S. Cobcroft, S. J. Towers, J. E. Smith, and A. Bruns, "Mobile learning in review: Opportunities and challenges for learners, teachers, and institutions," 2006.

[3] M. O. M. El-Hussein and J. C. Cronje, "Defining Mobile Learning in the Higher Education Landscape," Educational Technology \& Society, vol. 13, pp. 12-21, 2010.

[4] Y.-M. Huang, Y.-L. Jeng, and T.-C. Huang, "An Educational Mobile Blogging System for Supporting Collaborative Learning," Educational Technology \& Society, vol. 12, pp. 163-175, 2009.

[5] V. Venkatesh, M. G. Morris, G. B. Davis, and F. D. Davis, "User acceptance of information technology: Toward a unified view," MIS quarterly, pp. 425-478, 2003.

[6] W. H. DeLone and E. R. McLean, "Information systems success: the quest for the dependent variable," Information systems research, vol. 3, pp. 60-95, 1992.

[7] W. H. DeLone and E. R. McLean, "The DeLone and McLean Model of Information Systems Success: A Ten-Year Update," Journal of management information systems, vol. 19, pp. 9-30, Spring2003 2003.

[8] Y. S. Wang, M. C. Wu, and H. Y. Wang, "Investigating the determinants and age and gender differences in the acceptance of mobile learning," British Journal of Educational Technology, vol. 40, pp. 92 118, 2009.

[9] M. Fishbein and I. Ajzen, Belief, attitude, intention and behavior: An introduction to theory and research, 1975.

[10] F. D. Davis, "Perceived Usefulness, Perceived Ease of Use, and User Acceptance of Information Technology," MIS Quarterly, vol. 13, pp. 319-340, 1989.

[11] I. Ajzen, "The theory of planned behavior," Organizational behavior and human decision processes, vol. 50, pp. 179-211, 1991.

[12] F. D. Davis, R. P. Bagozzi, and P. R. Warshaw, "Extrinsic and intrinsic motivation to use computers in the workplace1," Journal of applied social psychology, vol. 22, pp. 1111-1132, 1992.

[13] A. Bandura, "Social foundations of thought and action," Englewood Cliffs, NJ, 1986.

[14] D. R. Compeau and C. A. Higgins, "Computer self-efficacy: Development of a measure and initial test," MIS quarterly, pp. 189-211, 1995.

[15] S. Taylor and P. Todd, "Assessing IT Usage: The Role of Prior Experience," MIS quarterly, vol. 19, pp. 561-570, 1995.

[16] H. Traindis, "Interpersonal behaviour," Brooks/Cole, Monterey, CA, 1977.

[17] R. L. Thompson, C. A. Higgins, and J. M. Howell, "Personal computing: toward a conceptual model of utilization," MIS quarterly, pp. 125-143, 1991.

[18] G. C. Moore and I. Benbasat, "Development of an instrument to measure the perceptions of adopting an information technology innovation," Information systems research, vol. 2, pp. 192-222, 1991.

[19] E. M. Rogers, Diffusion of innovations: Simon and Schuster, 2010.

[20] Y.-S. Wang, H.-Y. Wang, and D. Y. Shee, "Measuring e-learning systems success in an organizational context: Scale development and validation," Computers in Human Behavior, vol. 23, pp. 1792-1808, 2007.

[21] J. Heo and I. Han, "Performance measure of information systems (IS) in evolving computing environments: an empirical investigation," Information \& Management, vol. 40, pp. 243-256, 2003.

[22] G. G. Gable, D. Sedera, and T. Chan, "Enterprise systems success: a measurement model," 2003.

[23] B. L. Myers, L. A. Kappelman, and V. R. Prybutok, "A comprehensive model for assessing the quality and productivity of the information systems function: toward a theory for information systems assessment,"
Information Resources Management Journal (IRMJ), vol. 10, pp. 6-26, 1997.

[24] Q. Min, S. Ji, and G. Qu, "Mobile commerce user acceptance study in China: a revised UTAUT model," Tsinghua Science \& Technology, vol. 13, pp. 257-264, 2008.

[25] Y.-L. Wu, Y.-H. Tao, and P.-C. YangJ, "Using UTAUT to explore the behavior of 3G mobile communication users," in Industrial Engineering and Engineering Management, 2007 IEEE International Conference on, 2007, pp. 199-203.

[26] K. Jairak, P. Praneetpolgrang, and K. Mekhabunchakij, "An acceptance of mobile learning for higher education students in Thailand," in Sixth International Conference on eLearning for Knowledge-Based Society, Thailand, 2009, pp. 17-18.

[27] C. Carlsson, J. Carlsson, K. Hyvonen, J. Puhakainen, and P. Walden, "Adoption of mobile devices/services - searching for answers with the UTAUT," in System Sciences, 2006. HICSS'06. Proceedings of the 39th Annual Hawaii International Conference on, 2006, pp. 132a-132a.

[28] J. Park, S. Yang, and X. Lehto, "Adoption of mobile technologies for Chinese consumers," Journal of Electronic Commerce Research, vol. 8 , pp. 196-206, 2007.

[29] T. McGill, V. Hobbs, and J. Klobas, "User developed applications and information systems success: A test of DeLone and McLean's model," Information Resources Management Journal (IRMJ), vol. 16, pp. 24-45, 2003.

[30] P. B. Seddon, "A respecification and extension of the DeLone and McLean model of IS success," Information systems research, vol. 8, pp. 240-253, 1997.

[31] J. Etezadi-Amoli and A. F. Farhoomand, "A structural model of end user computing satisfaction and user performance," Information \& Management, vol. 30, pp. 65-73, 1996.

[32] D. L. Goodhue and R. L. Thompson, "Task-technology fit and individual performance," MIS quarterly, pp. 213-236, 1995.

[33] A. Barker, G. Krull, and B. Mallinson, "A proposed theoretical model for m-learning adoption in developing countries," in Proceedings of mLearn, 2005, p. 4th.

[34] M. Sharples, J. Taylor, and G. Vavoula, "Towards a theory of mobile learning," Proceedings of mLearn 2005, vol. 1, pp. 1-9, 2005.

[35] H. Sun and P. Zhang, "The role of moderating factors in user technology acceptance," International Journal of Human-Computer Studies, vol. 64, pp. 53-78, 2006.

[36] A. Rai, S. S. Lang, and R. B. Welker, "Assessing the validity of IS success models: An empirical test and theoretical analysis," Information Systems Research, vol. 13, pp. 50-69, 2002.

[37] R. Stockdale and M. Borovicka, "Using Quality Dimensions in the Evaluation of Websites," Information and Communication Technologies in Tourism 2006, pp. 344-344, 2006.

[38] I. Chang, Y.-C. Li, W.-F. Hung, and H.-G. Hwang, "An empirical study on the impact of quality antecedents on tax payers' acceptance of Internet tax-filing systems," Government Information Quarterly, vol. 22, pp. 389-410, 2005.

[39] B. H. Wixom and P. A. Todd, "A theoretical integration of user satisfaction and technology acceptance," Information systems research, vol. 16, pp. 85-102, 2005.

[40] P. Seddon and M.-Y. Kiew, "A partial test and development of DeLone and McLean's model of IS success," Australasian Journal of Information Systems, vol. 4, 2007.

[41] J. Roldán and A. Millán, "Analysis of the information systems success dimensions interdependence: An adaptation of the DeLone \& McLean's model in the Spanish EIS field," in BITWorld 2000. Conference Proceedings, 2000.

[42] S. Rivard, G. Poirier, L. Raymond, and F. Bergeron, "Development of a measure to assess the quality of user-developed applications," $A C M$ SIGMIS Database, vol. 28, pp. 44-58, 1997.

[43] P. E. Pedersen and R. Ling, "Modifying adoption research for mobile Internet service adoption: Cross-disciplinary interactions," in System Sciences, 2003. Proceedings of the 36th Annual Hawaii International Conference on, 2003, p. 10 pp. 
[44] A. T. Brubaker, "Faculty perceptions of the impact of student laptop use in a wireless internet environment on the classroom learning environment and teaching," Master's thesis, School of Information and Library Science, University of North Carolina, Chapel Hill, NC, 2006.

[45] J. Gikas and M. M. Grant, "Mobile computing devices in higher education: Student perspectives on learning with cellphones, smartphones \&amp; social media," The Internet and Higher Education, vol. 19, pp. 18-26, 2013.

[46] W. Alsaggaf, M. Hamilton, and J. Harland, "Mobile devices in computer programming lectures: Are CS lecturers prepared for mobile learning?," in Computer Science \& Education (ICCSE), 2012 7th International Conference on, 2012, pp. 1369-1374.

[47] A. Bryman and E. Bell, Business Research Methods. New York: Oxford University Press, 2011.

[48] J. Collis and R. Hussey, Business research: a practical guide for undergraduate and postgraduate students: Basingstoke : Palgrave Macmillan, 2009.

[49] K. B. Wright, "Researching Internet-based populations: Advantages and disadvantages of online survey research, online questionnaire authoring software packages, and web survey services," Journal of ComputerMediated Communication, vol. 10, pp. 00-00, 2005.
[50] A. Bryman, Social Research Methods. New York: Oxford University Press, 2012.

[51] U. Sekaran and R. Bougie, Research Methods for Business: A Skill Building Approach: John Wiley \& Sons, 2010.

[52] W. G. Zikmund, J. C. Carr, and M. Griffin, Business research methods: CengageBrain. com, 2012.

[53] L. J. Cronbach, "Coefficient alpha and the internal structure of tests," Psychometrika, vol. 16, pp. 297-334, 1951.

[54] J. Hair, W. Black, B. Babin, R. Anderson, and R. Tatham, "Multivariate Data Analysis: Pearson Education," New Jersey: Hoboken, 2006.

[55] J. C. Nunnally, Psychometric Theory: New York: McGraw-Hill, 1967.

[56] U. Sekaran, Research methods for business: A skill building approach: New York, USA: John Wiley \& Sons., 2006.

[57] D. De Vaus, Surveys in Social Research: Taylor \& Francis, 2002.

[58] C. P. Dancey and J. Reidy, Statistics Without Maths for Psychology: Prentice Hall, 2004.

[59] F. J. Fowler, Survey Research Methods, 4th ed.: SAGE Publications, 2009.

[60] T. Shih and X. Fan, "Comparing response rates from web and mail surveys: A meta-analysis," Field methods, vol. 20, pp. 249-271, 2008 


\section{Appendices}

\begin{tabular}{|c|c|c|c|c|c|c|}
\hline \multicolumn{7}{|c|}{$\begin{array}{c}\text { Mobile Learning-system usage: An integrated framework to measure students' behavioural intention } \\
\text { Scales and items }\end{array}$} \\
\hline \multicolumn{7}{|c|}{$\begin{array}{l}\text { Demographic Information } \\
\end{array}$} \\
\hline \multicolumn{2}{|c|}{ 1. $\quad$ Section I } & \multicolumn{5}{|c|}{ Demographic Characteristics Information } \\
\hline $\mathbf{Q}$ & Variable & \multicolumn{5}{|c|}{ Value } \\
\hline SUR & Are you taking this survey on a mobile device? & \multicolumn{5}{|c|}{$\begin{array}{l}\text { SUR1: } \square \text { Yes } \\
\text { SUR2: } \square \text { No }\end{array}$} \\
\hline AGE & In which category is your age? & \multicolumn{5}{|c|}{$\begin{array}{l}\text { AGE1: } \square 18-24 \text { years } \\
\text { AGE2: } \square 25-34 \text { years } \\
\text { AGE3: } \square 35-44 \text { years } \\
\text { AGE4: } \square \text { other, please specify: }\end{array}$} \\
\hline GEN & Please specify your gender & \multicolumn{5}{|c|}{$\begin{array}{l}\text { GEN1: } \square \text { Male } \\
\text { GEN2: } \square \text { Female }\end{array}$} \\
\hline EDU & Level of education(Current course) & \multicolumn{5}{|c|}{$\begin{array}{l}\text { EDU1: } \square \text { English language course } \\
\text { EDU2: } \square \text { Undergraduate course (e.g. Bachelor's degree) } \\
\text { EDU3: } \square \text { Graduate degree(Please specify: } \\
\text { EDU4: } \square \text { Other, please specify: }\end{array}$} \\
\hline OWN & $\begin{array}{l}\text { Please indicate the electronic equipment you currently own or plan to } \\
\text { buy in the next three months. (Select all that apply) }\end{array}$ & \multicolumn{5}{|c|}{$\begin{array}{l}\text { OWN1: } \square \text { Netbook } \\
\text { OWN2: } \square \text { Desktop } \\
\text { OWN3: } \square \text { Laptop } \\
\text { OWN4: } \square \text { Mobile phone (NOT Internet-capable) } \\
\text { OWN5: } \square \text { Internet-enabled mobile device (e.g., smartphone, tablet, etc.) } \\
\text { OWN6: } \square \text { Dedicated e-book device (e.g., Kindle, Nook, Sony Reader, etc.) } \\
\text { OWN7: } \square \text { MP3 Player } \\
\text { OWN8: } \square \text { Other ,please specify: }\end{array}$} \\
\hline DTPE & $\begin{array}{l}\text { Which of the following Internet-enabled mobile devices do you } \\
\text { currently use? (Select all that apply.) }\end{array}$ & \multicolumn{5}{|c|}{$\begin{array}{l}\text { DTPE1: } \square \text { iPhone } \\
\text { DTPE2: } \square \text { iPod Touch } \\
\text { DTPE3: } \square \text { iPad } \\
\text { DTPE4: } \square \text { Blackberry } \\
\text { DTPE5: } \square \text { Samsung } \\
\text { DTPE6: } \square \text { Other Android Mobile (Please specify) } \\
\text { DTPE7: } \square \text { Nexus One } \\
\text { DTPE8: } \square \text { I don't have a mobile device with Internet capabilities. } \\
\text { DTPE9: } \square \text { Other ,please specify: }\end{array}$} \\
\hline ACC & $\begin{array}{l}\text { What library/academic information or resources have you tried to } \\
\text { access using your mobile device? (Select all that apply). }\end{array}$ & \multicolumn{5}{|c|}{$\begin{array}{l}\text { ACC1: } \square \text { View library hours } \\
\text { ACC2: } \square \text { Ask a question } \\
\text { ACC3: } \square \text { Using the directory to view contact information } \\
\text { ACC4: } \square \text { Search library catalogue / databases } \\
\text { ACC5: } \square \text { Request an item through interlibrary loan } \\
\text { ACC6: } \square \text { Find out about labs } \\
\text { ACC7: } \square \text { View campus news } \\
\text { ACC8: } \square \text { View locations on the map } \\
\text { ACC9: } \square \text { View your timetable } \\
\text { ACC10: } \square \text { Renew library items } \\
\text { ACC11: } \square \text { None of these } \\
\text { ACC12: } \square \text { Other, please specify: }\end{array}$} \\
\hline USE & $\begin{array}{l}\text { To what degree do you use your Internet-enabled mobile device for } \\
\text { the following activities? }\end{array}$ & Always & Frequently & Occasionally & Rarely & Never \\
\hline USE1 & Social networking & $\begin{array}{l}1 \\
\square\end{array}$ & $\begin{array}{l}2 \\
\square\end{array}$ & $\begin{array}{l}3 \\
\square\end{array}$ & $\begin{array}{l}4 \\
\square\end{array}$ & $\begin{array}{l}5 \\
\square\end{array}$ \\
\hline USE2 & Reading content (e.g., e-books, articles, etc.) & $\begin{array}{l}1 \\
\square\end{array}$ & $\begin{array}{l}2 \\
\square\end{array}$ & $\begin{array}{l}3 \\
\square\end{array}$ & $\begin{array}{l}4 \\
\square\end{array}$ & $\begin{array}{l}5 \\
\square \\
\end{array}$ \\
\hline USE3 & Getting news alerts & $\begin{array}{l}1 \\
\square\end{array}$ & $\begin{array}{l}2 \\
\square\end{array}$ & $\begin{array}{l}3 \\
\square\end{array}$ & $\begin{array}{l}4 \\
\square\end{array}$ & $\begin{array}{l}5 \\
\square\end{array}$ \\
\hline
\end{tabular}




\begin{tabular}{|c|c|c|c|c|c|c|c|c|c|}
\hline USE4 & \multicolumn{2}{|l|}{ Accessing email } & & $\begin{array}{l}1 \\
\square\end{array}$ & $\begin{array}{l}2 \\
\square\end{array}$ & \multicolumn{2}{|c|}{$\begin{array}{l}3 \\
\square\end{array}$} & $\begin{array}{l}4 \\
\square\end{array}$ & $\begin{array}{l}5 \\
\square\end{array}$ \\
\hline USE5 & \multicolumn{2}{|l|}{ Text messaging } & & $\begin{array}{l}1 \\
\square\end{array}$ & 2 & \multicolumn{2}{|c|}{3} & $\begin{array}{l}4 \\
\square\end{array}$ & $\begin{array}{l}5 \\
\square\end{array}$ \\
\hline USE6 & \multicolumn{2}{|l|}{ Searching for information } & & $\begin{array}{l}1 \\
\square\end{array}$ & $\begin{array}{l}2 \\
\square\end{array}$ & \multicolumn{2}{|c|}{$\begin{array}{l}3 \\
\square\end{array}$} & $\begin{array}{l}4 \\
\square\end{array}$ & $\begin{array}{l}5 \\
\square\end{array}$ \\
\hline USE7 & \multicolumn{2}{|l|}{ Getting directions } & & $\begin{array}{l}1 \\
\square\end{array}$ & $\begin{array}{l}2 \\
\square\end{array}$ & \multicolumn{2}{|c|}{$\square$} & $\begin{array}{l}4 \\
\square\end{array}$ & $\begin{array}{l}5 \\
\square\end{array}$ \\
\hline USE8 & \multicolumn{2}{|l|}{ Uploading content } & & $\begin{array}{l}1 \\
\square\end{array}$ & 2 & \multicolumn{2}{|c|}{3} & $\begin{array}{l}4 \\
\square\end{array}$ & $\begin{array}{l}5 \\
\square\end{array}$ \\
\hline USE9 & \multicolumn{2}{|l|}{ Playing games } & & $\begin{array}{l}1 \\
\square\end{array}$ & 2 & \multicolumn{2}{|c|}{$\square$} & $\begin{array}{l}4 \\
\square\end{array}$ & $\begin{array}{l}5 \\
\square\end{array}$ \\
\hline USE10 & \multicolumn{2}{|l|}{ Listening to music or watching videos } & & $\begin{array}{l}1 \\
\square\end{array}$ & $\begin{array}{l}2 \\
\square\end{array}$ & \multicolumn{2}{|c|}{$\begin{array}{l}3 \\
\square\end{array}$} & $\begin{array}{l}4 \\
\square\end{array}$ & $\begin{array}{l}5 \\
\square\end{array}$ \\
\hline \multicolumn{10}{|c|}{$\begin{array}{c}\text { Continued: Mobile Learning-system usage: An integrated framework to measure students' behavioural intention } \\
\text { Scales and items }\end{array}$} \\
\hline USE11 & \multicolumn{2}{|l|}{ Completing coursework or participating in lectures } & & \begin{tabular}{l|l}
1 \\
$\square$
\end{tabular} & $\begin{array}{l}2 \\
\square\end{array}$ & \multicolumn{2}{|c|}{$\begin{array}{l}3 \\
\square\end{array}$} & $\begin{array}{l}4 \\
\square\end{array}$ & $\begin{array}{l}5 \\
\square\end{array}$ \\
\hline GAPP & Have you used Griffith University Application for mobile dev & ces? & & $\begin{array}{l}\mathrm{P} 1 \mathrm{:} \square \mathrm{Ye} \\
\mathrm{P} 2: \square \mathrm{No} \\
\text { P3: } \square \mathrm{I} \mathrm{pl} \\
\mathrm{PP} 4: \square \mathrm{I} \text { us } \\
\text { P5: } \square \text { I di }\end{array}$ & $\begin{array}{l}\text { es } \\
\text { lan to use it sed before, } \\
\text { lid not know }\end{array}$ & $\begin{array}{l} \\
\text { not any } \\
\text { is an a }\end{array}$ & & & \\
\hline & UTAUT(adapted from Vt & kate & Mo & is, Davis, & \& Davis (20 & & & & \\
\hline 2. & Section II & & & & & forma & Expect: & & \\
\hline & & & & $\begin{array}{l}\text { ongly } \\
\text { agree }\end{array}$ & & Neutr & & & ongly Agree \\
\hline PEE1 & I feel that mobile learning is useful. & & & 1 & $\begin{array}{l}2 \\
\square\end{array}$ & 4 & $\begin{array}{l}5 \\
\square\end{array}$ & $\begin{array}{l}6 \\
\square\end{array}$ & $\begin{array}{l}7 \\
\square\end{array}$ \\
\hline PEE2 & Mobile learning improves my study efficiency. & & & $\begin{array}{l}1 \\
\square\end{array}$ & $\begin{array}{l}2 \\
\square\end{array}$ & $\begin{array}{l}4 \\
\square\end{array}$ & $\begin{array}{l}5 \\
\square\end{array}$ & $\begin{array}{l}6 \\
\square\end{array}$ & $\begin{array}{l}7 \\
\square\end{array}$ \\
\hline PEE3 & Mobile learning improves my study convenience. & & & 1 & $\overline{2}$ & $\begin{array}{l}4 \\
\square\end{array}$ & $\begin{array}{l}5 \\
\square\end{array}$ & $\begin{array}{l}6 \\
\square\end{array}$ & 7 \\
\hline PEE4 & Mobile learning lets me do study related tasks more quickly. & & & $\begin{array}{l}1 \\
\square\end{array}$ & $\begin{array}{l}2 \\
\square\end{array}$ & $\begin{array}{l}4 \\
\square\end{array}$ & $\begin{array}{l}5 \\
\square\end{array}$ & $\begin{array}{l}6 \\
\square\end{array}$ & $\begin{array}{l}7 \\
\square \\
\end{array}$ \\
\hline 3. & Section III & & & & & Effort & pectanc & & \\
\hline & & $\begin{array}{l}\text { Stro } \\
\text { Disa }\end{array}$ & & & & tral & & & rongly Agree \\
\hline EFE1 & Skilfully using mobile learning is easy for me. & & & $\begin{array}{l}2 \\
\square\end{array}$ & $\begin{array}{l}3 \\
\square\end{array}$ & $\begin{array}{l}4 \\
\square\end{array}$ & $\begin{array}{l}5 \\
\square\end{array}$ & $\begin{array}{l}6 \\
\square\end{array}$ & $\begin{array}{l}7 \\
\square\end{array}$ \\
\hline EFE2 & I find that using mobile learning is easy. & & & $\begin{array}{l}2 \\
\square\end{array}$ & $\begin{array}{l}3 \\
\square\end{array}$ & $\begin{array}{l}4 \\
\square\end{array}$ & $\begin{array}{l}5 \\
\square\end{array}$ & $\begin{array}{l}6 \\
\square\end{array}$ & $\begin{array}{l}7 \\
\square\end{array}$ \\
\hline EFE3 & Learning how to use mobile learning is easy for me. & & & $\begin{array}{l}2 \\
\square\end{array}$ & $\begin{array}{l}3 \\
\square\end{array}$ & $\begin{array}{l}4 \\
\square\end{array}$ & $\begin{array}{l}5 \\
\square\end{array}$ & $\begin{array}{l}6 \\
\square \\
\end{array}$ & $\begin{array}{l}7 \\
\square \\
\end{array}$ \\
\hline EFE4 & $\begin{array}{l}\text { My interaction with mobile learning is clear and } \\
\text { understandable. }\end{array}$ & & & $\begin{array}{l}2 \\
\square\end{array}$ & $\begin{array}{l}3 \\
\square\end{array}$ & $\begin{array}{l}4 \\
\square\end{array}$ & $\begin{array}{l}5 \\
\square\end{array}$ & $\begin{array}{l}6 \\
\square\end{array}$ & $\begin{array}{l}7 \\
\square\end{array}$ \\
\hline 4. & Section IV & & & & & Socia & Ifluence & & \\
\hline & & & & & & eutral & & & $\begin{array}{c}\text { Strongly } \\
\text { Agree }\end{array}$ \\
\hline SOI1 & $\begin{array}{l}\text { Those people that influence my behaviour think that I } \\
\text { should use mobile learning }\end{array}$ & & & $\begin{array}{l}2 \\
\square\end{array}$ & $\begin{array}{l}3 \\
\square\end{array}$ & 4 & $\begin{array}{l}5 \\
\square\end{array}$ & $\begin{array}{l}6 \\
\square\end{array}$ & 7 \\
\hline SOI2 & $\begin{array}{l}\text { Those people that are important to me think that I should use } \\
\text { mobile learning }\end{array}$ & & & $\begin{array}{l}2 \\
\square\end{array}$ & $\begin{array}{l}3 \\
\square\end{array}$ & $\begin{array}{l}4 \\
\square\end{array}$ & $\begin{array}{l}5 \\
\square\end{array}$ & $\begin{array}{l}6 \\
\square\end{array}$ & $\begin{array}{l}7 \\
\square\end{array}$ \\
\hline 5. & Section X & & & & & vioura & tention & Use & \\
\hline & & & & & & Neutral & & & $\begin{array}{c}\text { Strongly } \\
\text { Agree }\end{array}$ \\
\hline
\end{tabular}




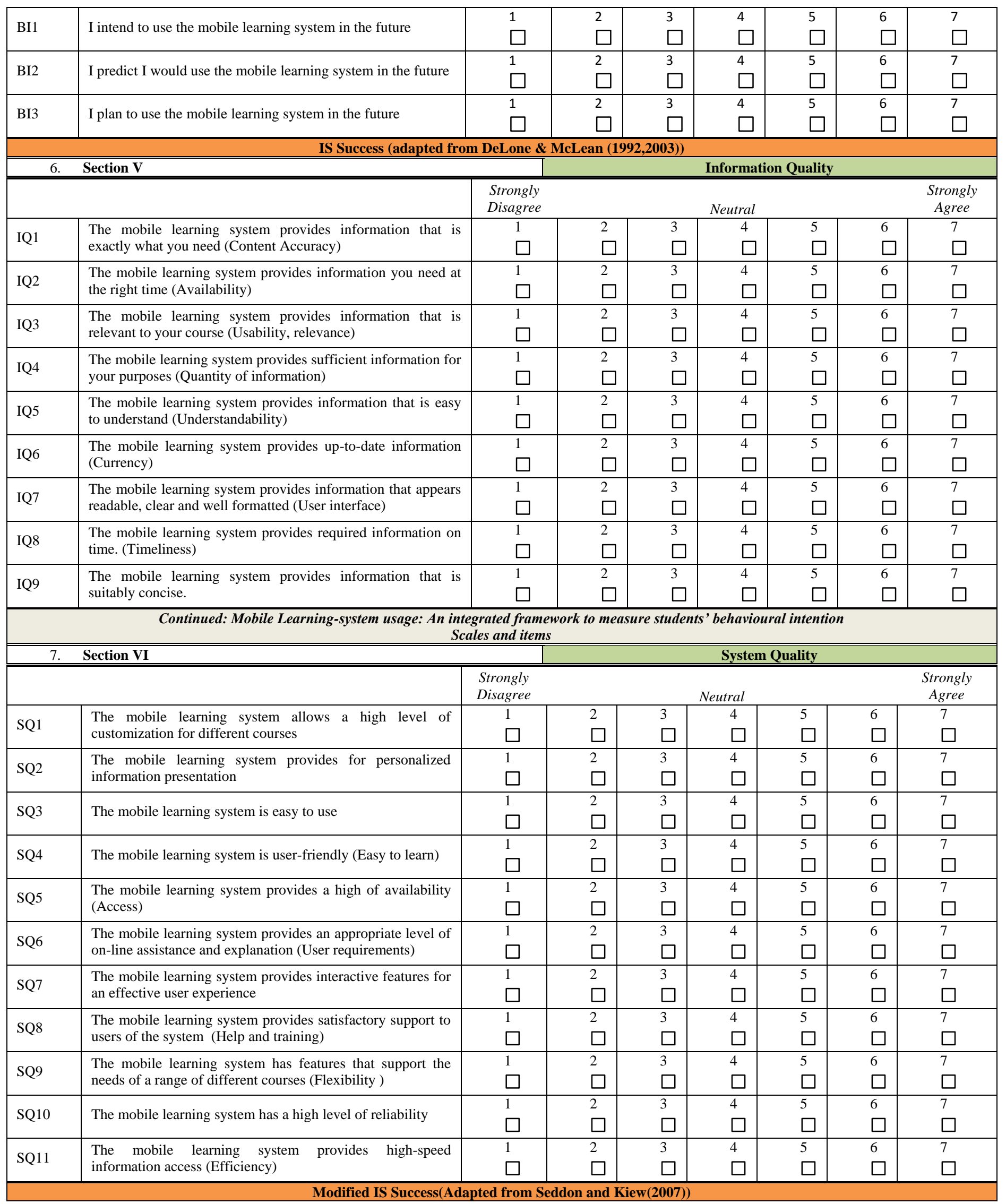


(IJARAI) International Journal of Advanced Research in Artificial Intelligence,

Vol. 3, No.11, 2014

Extended Paper from Science and Information Conference 2014

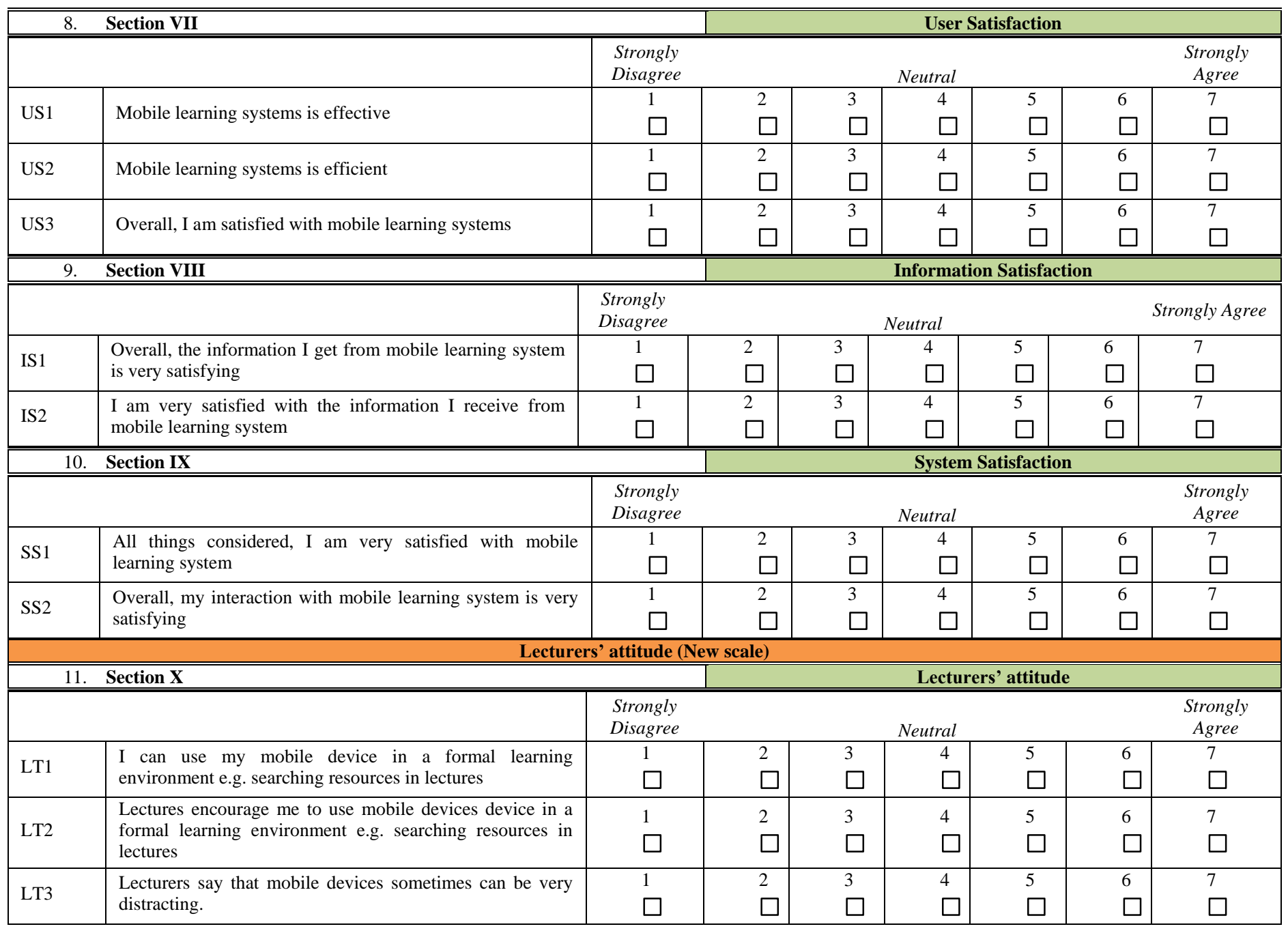

